\title{
Diagnosis by real-time polymerase chain reaction of pathogens and antimicrobial resistance genes in bone marrow transplant patients with bloodstream infections
}

\author{
Liana Carballo Menezes ${ }^{1,2}$, Talita Trevizani Rocchetti ${ }^{1,2}$, Karen de Castro Bauab ${ }^{1,2}$, Paola Cappellano2, \\ Milene Gonçalves Quiles ${ }^{1,2}$, Fabianne Carlesse ${ }^{3}$, Jose Salvador Rodrigues de Oliveira ${ }^{4}$ \\ and Antonio Carlos Campos Pignatari ${ }^{1,2^{*}}$
}

\begin{abstract}
Background: Early identification of pathogens and antimicrobial resistance in bloodstream infections (BSIs) decreases morbidity and mortality, particularly in immunocompromised patients. The aim of the present study was to compare real-time polymerase chain reaction (PCR) with commercial kits for detection of 17 pathogens from blood culture (BC) and 10 antimicrobial resistance genes.

Methods: A total of 160 BCs were taken from bone marrow transplant patients and screened with Gram-specific probes by multiplex real-time PCR and 17 genus-specific sequences using TaqMan probes and blaSHV, blaTEM, blaCTX, blaKPC, blaIMP, blaSPM, blaVIM, vanA, vanB, and mecA genes by SYBR Green.
\end{abstract}

Results: Twenty-three of 33 samples identified by phenotypic testing were concordantly positive by $B C$ and real-time PCR. Pathogen identification was discordant in 13 cases. In 12 of 15 coagulase-negative staphylococci, the mecA gene was detected and four Enterococcus spp. were positive for vanA. Two blaCTX and three blaSHV genes were found by quantitative PCR. The blaKPC and metallo- $\beta$-lactamase genes were not detected. Five fungal species were identified only by real-time PCR.

Conclusions: Real-time PCR could be a valuable complementary tool in the management of BSI in bone marrow transplants patients, allowing identification of pathogens and antimicrobial resistance genes.

Keywords: Bone marrow transplants, Real-time polymerase chain reaction, Antibiotic resistance genes, Bloodstream infections

\section{Background}

Approximately $60 \%$ of episodes of fever in patients with neutropenia are frequently correlated with documented bloodstream infection (BSI). BSI is associated with high morbidity and a mortality rate ranging from 20 to $70 \%$. The SENTRY Antimicrobial Surveillance Program (19972002) reported that 10 bacterial species accounted for

\footnotetext{
* Correspondence: pignatari@terra.com.br

'Special Clinical Microbiology Laboratory (LEMC), Federal University of São Paulo/UNIFESP, São Paulo, Brazil

${ }^{2}$ Division of Infectious Diseases, Federal University of São Paulo/UNIFESP, São Paulo, Brazil

Full list of author information is available at the end of the article
}

89-92\% of all isolates in 659,935 cases of sepsis reported in the United States in 2000. The ranking of microorganisms was similar across North America, Latin America, and Europe [1]. The rank of the five major pathogens in the Brazilian SCOPE (Surveillance and Control of Pathogens of Epidemiological Importance) were Staphylococcus aureus (15.4\%), coagulase-negative staphylococci (CoNS) (13.4\%), Klebsiella spp. (13.2\%), Acinetobacter spp. (12.5\%), and Pseudomonas aeruginosa (8.9\%) [2].

The most dangerous clinical manifestations of BSI are sepsis and shock, which are the 10th leading cause of death in the United States, accounting for 6\% of all deaths (50.37 deaths per 100,000 individuals in the 
overall population) [3]. Early diagnosis of sepsis and provision of appropriate antimicrobial therapy correlate with positive clinical outcomes [4]. Blood culture (BC) is considered to be the gold standard for detecting microorganisms in the bloodstream, including those that have antibiotic resistance genes [5]. Molecular amplification techniques have been used to detect microorganisms in BSI. Automated BC systems take 1-2 days, on average, to signal a positive result and a further 1-2 days to finalize bacterial identification and antimicrobial testing. Rapid detection of bacterial resistance mechanisms in $\mathrm{BC}$ bottles can assist physicians with both patient management and infection control.

\section{Methods \\ Patients}

During October 2008 to July 2011, 160 BCs from Bactec bottles were analyzed from 33 immunocompromised patients (31 adults and two children) with hematological malignancies who underwent bone marrow transplantation (seven acute myeloid leukemia, six multiple myeloma, six non-Hodgkin's lymphoma, four acute lymphoblastic leukemia, two Hodgkin's disease, two chronic myeloproliferative disorders, one chronic lymphoblastic leukemia, one adenovirus dystrophia, one Ewing syndrome, one pineal carcinoma and one testicular cancer). Patients were admitted to the Institute of Pediatric Oncology (GRAACC) and the Adult Hematology Unit of São Paulo Hospital, Federal University of São Paulo, Brazil. Informed consent was obtained from patients and the study was approved by the Clinical Research Ethics Committee of the hospital.

\section{Sample collection and bacterial identification}

The samples were collected as part of standard patient care from patients suspected of BSI in the pretransplant mobilization phase of hematopoietic stem cell transplantation, transplanted patients, and patients admitted with clinical complications after transplantation. At the onset of fever $\left(>37^{\circ} \mathrm{C}\right)$ or in the presence of any clinical symptom compatible with infection, two sets of BCs were taken. BSI was defined as the isolation of a bacterial or fungal pathogen from at least one BC. For CoNS, corynebacteria other than Corynebacterium jeikeium and common skin contaminants, at least two sets of positive BCs were required. All episodes of BSI were then subclassified as single-agent (Gram-positive, Gram-negative or fungal) or polymicrobial. For polymicrobial BSI, two or more pathogens were isolated from a single $\mathrm{BC}$ or at least two separate BCs at $96 \mathrm{~h}$ apart. BCs were performed using the Bactec 9240 (Becton Dickinson, Microbiology Systems, Cockeysville, MD, USA). BC bottles were signaled positive by Bactec 9240 after detection of bacterial growth. The samples were negative by Bactec when no bacterial growth was detected after 5 days incubation.
Identification to species level and susceptibility testing were performed using the automated system Phoenix 100 (Becton Dickinson Microbiology Systems).

\section{DNA extraction}

Total DNA was extracted from the positive or negative $500-\mu \mathrm{l} \mathrm{BC}$ broth after incubation on Bactec 9240 , using the phenol-chloroform method (Brazol; LGC Biotechnologia, Cotia, Brazil) with $300 \mathrm{mg}$ glass beads $(0.3 \mathrm{~mm}$ diameter; Scientific Industries, Bohemia, NY, USA) and processed in a disruptor Genie (Scientific Industries) for $10 \mathrm{~min}$ to achieve cell lysis.

\section{Primers and TaqMan probe}

The primers used for detection of the resistance genes, blaSHV, blaTEM, blaCTX-M, blaIMP, blaSPM, blaVIM, blaKPC, vanA, vanB and mecA, have been described previously [6]. The TaqMan probes for multiplex realtime polymerase chain reaction (PCR) detection of Gram-positive and Gram-negative bacteria have been previously described, as well as species-specific TaqMan probes for detection of Enterococcus spp., CoNS, $S$. aureus, Streptococcus pneumoniae, Escherichia coli, Klebsiella pneumoniae, Enterobacter cloacae, Proteus mirabilis, Salmonella spp., Serratia marcescens, Acinetobacter baumannii, P. aeruginosa, Stenotrophomonas maltophilia, Mycobacterium tuberculosis, Aspergillus spp., Candida spp. and Fusarium spp. [7]. All the primers and probes were selected from the National Center for Biotechnology Information website (NCBI; http://www.ncbi.nlm.nih.gov) and synthesized by Applied Biosystems (Foster City, CA, USA). The primers were checked for specificity in a BLAST search available through the NCBI website (http://blast.ncbi.nlm.nih.gov/Blast.cgi). A primer set for the hemochromatosis gene was designed to be used as an internal control.

\section{Real-time PCR}

Detection of bacterial DNA was screened using universal primers of $16 \mathrm{~S}$ rDNA gene. Differentiation between Gram-positive and Gram-negative bacteria was done by TaqMan multiplex real-time PCR [7]. Differentiation of the other genes was performed by monoplex real-time PCR. Amplification for TaqMan probes reactions was performed in a $20-\mu \mathrm{l}$ reaction volume, using $10 \mu \mathrm{l}$ TaqMan Universal Master Mix 2X (Applied Biosystems), $5 \mu \mathrm{l}$ template DNA, $0.5 \mu \mathrm{M}$ each primer, and $0.3 \mu \mathrm{M}$ probe. The real-time PCR conditions were as follows: $50^{\circ} \mathrm{C}$ for $2 \mathrm{~min}$ and $95^{\circ} \mathrm{C}$ for $10 \mathrm{~min} ; 40$ cycles of $95^{\circ} \mathrm{C}$ for $15 \mathrm{~s}$ and $60^{\circ} \mathrm{C}$ for $60 \mathrm{~s}$. Resistance genes amplification by SYBR Green monoplex real-time PCR was performed in a $25-\mu \mathrm{l}$ reaction mixture containing $12.5 \mu \mathrm{l}$ Platinum SYBR Green qPCR SuperMix (Invitrogen, Carlsbad, CA, USA), $0.5 \mu \mathrm{M}$ each primer, and $5 \mu \mathrm{l}$ purified DNA 
extracted from samples. The real-time PCR conditions were as follows: $50^{\circ} \mathrm{C}$ for $2 \mathrm{~min}$ and $95^{\circ} \mathrm{C}$ for $10 \mathrm{~min}$; 40 cycles of $95^{\circ} \mathrm{C}$ for $15 \mathrm{~s}$ and $60^{\circ} \mathrm{C}$ for $60 \mathrm{~s}$; and a melting curve step (from $68^{\circ} \mathrm{C}$ to $95^{\circ} \mathrm{C}$ in increments of $0.5^{\circ} \mathrm{C} / \mathrm{s}$ ). The metallo- $\beta$-lactamase amplification was performed by multiplex real-time PCR [7]. The ABI 7500 real-time PCR System (Applied Biosystems) instrument was quantified online and at the endpoint with the sequence detection system software (version 2.0; Applied Biosystems).

\section{Data analysis}

Data collection and statistical analysis were performed using SSPS version 17.0 software (SPSS Inc., Chicago, IL, USA) and Microsoft Office Excel 2007 (Microsoft, Redmond, WA, USA). The area under the receiver operating characteristic curve (AUC) was determined for binary diagnostic test results for all genes. Comparison of the $\mathrm{BC}$ identification by Phoenix versus real-time PCR results were evaluated by $\chi^{2}$ tests. Discordance between the results from the two methods was assessed using McNemar's test (statistical significance was set at a two-tailed exact test, based on the binomial distribution with $\mathrm{p}=\mathrm{q}=0.5$ ). The $\mathrm{\kappa}$ statistic was calculated to measure the level of agreement between BC by Phoenix and real-time PCR results.

\section{Results}

\section{Sample collection and bacterial identification}

A total of 160 blood samples collected from 33 patients were evaluated for BSI. Thirty-three samples, representing 15 febrile episodes, tested positive by BC. BC identified 23 Gram-positive bacteria (15 CoNS, four Enterococcus faecium, two Enterococcus faecalis and two Str. pneumoniae) and 10 Gram-negative bacteria [one Pseudomonas putida, two Acinetobacter spp., three Ent. cloacae, one $K$. pneumoniae, one E. coli, one nonfermenting Gram-negative bacilli (NFGNB) and one Citrobacter freundii].

\section{Real-time PCR}

Real-time PCR detected 37 positive samples (Table 1). The data for negative samples by the two methods are not shown. Twenty-three of 33 samples identified by phenotypic testing were concordantly positive by BC and real-time PCR (Table 1). Twenty-one samples were discordant by both methods. Nine BC-positive samples were negative by real-time $\mathrm{PCR}$ and $12 \mathrm{BC}$-negative samples were positive by PCR.

Table 1 shows only positive samples that were isolated by $\mathrm{BC}$ and/or real-time PCR. The other 21 negative results are not shown.

For Gram-positive bacteria, 15 CoNS were positive by $\mathrm{BC}$ and 13 of these were detected by real-time PCR.
Three CoNS were detected by real-time PCR but did not grow in culture. Three of six BCs that were positive for Enterococcus spp. were negative by real-time PCR, while whereas $\mathrm{BC}$ did not detect one sample that was positive by real-time PCR. In two samples, BC identified Str. Pneumoniae, while real-time PCR was not positive for one of these samples.

For Gram-negative bacteria, all Ent. cloacae and E. coli samples were concordant by both methods (Table 1). In three samples, growth of $C$. freundii, Acinetobacter spp. and P. putida was detected by $\mathrm{BC}$ and by Gramnegative probe; however, specific primers and probes were not designed for these pathogens, therefore they were not considered discrepant. Two samples were positive for $K$. pneumoniae by real-time PCR and negative by $\mathrm{BC}$, whereas one $\mathrm{BC}$-positive sample was negative by real-time PCR. Three samples were identified as A. baumannii by real-time PCR and one of these was positive by $\mathrm{BC}$, one was $\mathrm{BC}$-positive for NFGNB, and one was not detected by $\mathrm{BC}$.

The overall concordance level was $72.7 \%$ for phenotypic and real-time PCR methods with a Cohen $\kappa$ coefficient of 0.7 (95\% CI: 0.61-0.80).

For resistance genes, real-time PCR detected 12 CoNS with mecA genes. Nine samples were concordant for detection of the mecA gene compared with phenotypic resistance to methicillin. The $v a n A$ gene was detected in four Enterococcus spp. (Enter. faecalis and Enter. faecium) and none were positive for the $\operatorname{van} \mathrm{B}$ gene. The concordance was $100 \%$ between two vancomycin resistance methods (Table 1 ).

For Gram-negative bacteria, five samples detected the ES $\beta \mathrm{L}$ gene by real-time PCR. The blaSHV gene was detected in three samples and blaCTX-M in two (Table 1). Only two of the five positive ES $\beta L$ real-time PCR samples were identified by the phenotypic method as ES $\beta L$ producers; the other two were identified as ES $\beta \mathrm{L}$ producers by the phenotypic method but were negative by real-time PCR (Table 1).

The blaKPC and metallo- $\beta$-lactamase genes were not detected. The A. baumannii samples showed carbapenem phenotypic resistance; however, the carbapenemase genes were not detected.

Three Candida spp. were detected from two patients by real-time PCR but not by $\mathrm{BC}$. In one patient, two samples were positive by real-time PCR. Two samples were positive for Aspergillus spp. by real-time PCR with negative galactomannan antigenemia. Fusarium spp. were not detected.

Real-time PCR performance for bacterial identification was adjusted as follows: sensitivity, $78 \%$; specificity, $93 \%$; negative predictive value (NPV), 95\%; positive predictive value (PPV), 72\% when compared with the phenotypic method. 
Table 1 Results of real-time PCR, culture identification and antimicrobial susceptibility of positive samples from BC bottles

\begin{tabular}{|c|c|c|c|c|c|c|c|}
\hline \multirow[t]{5}{*}{ Patients } & \multirow{2}{*}{$\begin{array}{c}\begin{array}{c}\text { Date } \\
\text { samples }\end{array} \\
10 / 9 / 2009\end{array}$} & \multirow{2}{*}{$\begin{array}{c}\text { Bactec }^{\circledR} \text { Results } \\
\text { Positive }\end{array}$} & \multirow{2}{*}{$\begin{array}{c}\begin{array}{c}\text { Bacterial isolated from } \\
\text { blood culture (Phoenix }{ }^{\circledR} \text { ) }\end{array} \\
\text { S. epidermidis }\end{array}$} & \multirow{2}{*}{$\begin{array}{c}\text { Bacterial detected } \\
\text { with the PCR test }\end{array}$} & \multicolumn{2}{|c|}{$\begin{array}{l}\text { Antimicrobial susceptibility } \\
\left(\text { (Phoenix }^{\circledR}\right)\end{array}$} & \multirow{2}{*}{$\begin{array}{c}\text { Resistance genes by } \\
\text { real-time PCR } \\
\text { mecA }\end{array}$} \\
\hline & & & & & $\mathrm{S}^{*}$ & Oxacilin & \\
\hline & 10/9/2009 & Positive & S. epidermidis & CoNS & $S$ & Oxacilin & mecA \\
\hline & 10/9/2009 & Positive & S. epidermidis & CoNS & $S$ & Oxacilin & mecA \\
\hline & & & & & & Cephalosporins & \\
\hline \multirow{6}{*}{01} & $12 / 20 / 2009$ & Positive & C.freundii & CoNS & $S$ & and & ND \\
\hline & & & & & & Carbapenems & \\
\hline & $12 / 20 / 2009$ & Positive & S. epidermidis & CoNS & $\mathrm{R}^{*}$ & Oxacilin & mecA \\
\hline & $3 / 1 / 2009$ & Negative & ND & CoNS and GN & NA & NA & blaSHV \\
\hline & $1 / 9 / 2010$ & Negative & ND & Aspergillus spp. & NA & NA & NA \\
\hline & $12 / 4 / 2008$ & Positive & E. cloacae & E. cloacae & $\mathrm{R}$ & Cephalosporins & ND \\
\hline \multirow{3}{*}{02} & $12 / 4 / 2008$ & Positive & E. cloacae & E. cloacae & $R$ & Cephalosporins & ND \\
\hline & $12 / 4 / 2008$ & Positive & E. cloacae & E. cloacae & $\mathrm{R}$ & Cephalosporins & blaSHV \\
\hline & $3 / 5 / 2009$ & Positive & CoNS & CoNS & $\mathrm{R}$ & Oxacilin & mecA \\
\hline \multirow{3}{*}{03} & $3 / 5 / 2009$ & Positive & CoNS & CoNS & R & Oxacilin & mecA \\
\hline & $3 / 5 / 2009$ & Positive & CoNS & CoNS & $R$ & Oxacilin & ND \\
\hline & $5 / 8 / 2009$ & Positive & P. putida & ND & NA & NA & ND \\
\hline \multirow{2}{*}{04} & $5 / 8 / 2009$ & Positive & S. epidermidis & CoNS & $\mathrm{R}$ & Oxacilin & mecA \\
\hline & $5 / 8 / 2009$ & Positive & S. epidermidis & CONS & $R$ & Oxacilin & mecA \\
\hline \multirow{3}{*}{05} & $8 / 2 / 2009$ & Positive & S. pneumoniae & ND & S & Penicilin & ND \\
\hline & $8 / 2 / 2009$ & Positive & S. pneumoniae & S. pneumoniae & $\mathrm{S}$ & Penicilin & ND \\
\hline & $6 / 6 / 2009$ & Positive & E. faecium & Enterococcus spp. & $\mathrm{R}$ & Glycopeptide & $\operatorname{vanA}$ \\
\hline \multirow{2}{*}{06} & $6 / 6 / 2009$ & Positive & E. faecium & ND & $R$ & Glycopeptide & $\operatorname{vanA}$ \\
\hline & $6 / 6 / 2009$ & Positive & E. faecium & ND & $\mathrm{R}$ & Glycopeptide & vanA \\
\hline \multirow{6}{*}{07} & $1 / 18 / 2009$ & Positive & NFGNB & A. baumannii & $\mathrm{R}$ & $\begin{array}{l}\text { Cephalosporins and } \\
\text { Carbapenems }\end{array}$ & ND \\
\hline & & & & & & Cephalosporins & \\
\hline & $1 / 31 / 2009$ & Positive & Acinetobacter spp. & ND & $\mathrm{R}$ & and & ND \\
\hline & & & & & & Carbapenems & \\
\hline & $1 / 31 / 2009$ & Negative & ND & A. baumannii & NA & NA & ND \\
\hline & & & & & $\mathrm{R}$ & Cephalosporins & \\
\hline \multirow{2}{*}{08} & $3 / 2 / 2009$ & Positive & K. pneumoniae & ND & and & and & ND \\
\hline & & & & & $S$ & Carbapenems & \\
\hline \multirow{2}{*}{09} & 9/28/2009 & Positive & E. faecalis & ND & $S$ & Glycopeptide & ND \\
\hline & $9 / 28 / 2009$ & Positive & E. faecalis & Enterococcus spp. & $S$ & Glycopeptide & ND \\
\hline \multirow{2}{*}{10} & $12 / 12 / 2008$ & Positive & E. faecium & Enterococcus spp. & $R$ & Glycopeptide & $\operatorname{van} A$ \\
\hline & $12 / 9 / 2008$ & Negative & ND & Enterococcus spp. & NA & NA & ND \\
\hline \multirow{5}{*}{11} & $12 / 18 / 2008$ & Negative & ND & K. pneumoniae & NA & NA & blactX-M \\
\hline & $12 / 21 / 2008$ & Negative & ND & K. pneumoniae & NA & NA & blactX-M \\
\hline & $2 / 21 / 2009$ & Negative & ND & CoNS and GN & NA & NA & ND \\
\hline & $28 / 03 / 2011$ & Negative & ND & CONS & NA & NA & ND \\
\hline & $2 / 21 / 2009$ & Negative & ND & Candida spp. & NA & NA & $N A$ \\
\hline \multirow{3}{*}{12} & $4 / 8 / 2011$ & Positive & S. epidermidis & CONS & $R$ & Oxacilin & mecA \\
\hline & $4 / 8 / 2011$ & Positive & S. epidermidis & CONS & $\mathrm{R}$ & Oxacilin & mecA \\
\hline & $4 / 8 / 2011$ & Positive & S. epidermidis & CONS & $\mathrm{R}$ & Oxacilin & mecA \\
\hline 13 & $3 / 14 / 2009$ & Negative & ND & ND & NA & NA & blaSHV \\
\hline
\end{tabular}


Table 1 Results of real-time PCR, culture identification and antimicrobial susceptibility of positive samples from BC bottles (Continued)

\begin{tabular}{|c|c|c|c|c|c|c|c|}
\hline 14 & $11 / 4 / 2010$ & Positive & A. baumannii & A. baumannii & $S$ & Cephalosporins & $N D$ \\
\hline 15 & $3 / 26 / 2011$ & Positive & E. coli & E. coli & $S$ & $\begin{array}{c}\text { Cephalosporins and } \\
\text { Carbapenems }\end{array}$ & $N D$ \\
\hline 16 & $3 / 31 / 2011$ & Positive & S. epidermidis & CONS & $\mathrm{R}$ & Oxacilin & mecA \\
\hline \multirow{2}{*}{17} & $5 / 8 / 2009$ & Positive & CoNS & $N D$ & $\mathrm{R}$ & Oxacilin & $N D$ \\
\hline & $5 / 8 / 2009$ & Positive & CoNS & $N D$ & $\mathrm{R}$ & Oxacilin & $N D$ \\
\hline 18 & $5 / 14 / 2009$ & Negative & ND & Aspergillus spp. & NA & NA & $N A$ \\
\hline \multirow{2}{*}{19} & $5 / 2 / 2009$ & Negative & ND & Candida albicans & NA & NA & $N A$ \\
\hline & $5 / 4 / 2009$ & Negative & ND & Candida albicans & NA & NA & $N A$ \\
\hline
\end{tabular}

R: Resistant; S: Susceptible; * CLSI 2010; NA: results not available; ND: Not Detected.

\section{Discussion}

Early identification of the causative pathogen in BSI is crucial, especially in transplant patients, and can improve survival in the post-transplant period. In addition, rapid detection of resistance genes in the bloodstream can contribute to the efficacy of antimicrobial treatment with reduced morbidity/mortality [8-10].

The use of PCR for diagnostic purposes has established a new era in the detection and characterization of microorganisms directly from clinical samples. Several protocols based on PCR amplification of $16 \mathrm{~S}$ rDNA for differentiation of Gram-positive and Gram-negative bacteria have been used with samples collected from different infectious sites $[11,12]$.

Commercially available multiplex real-time PCR assay kits have been evaluated in adult patients with hematological malignancies and compared with $\mathrm{BC}$ for identification of microorganisms [13]. Our study reports the clinical application of real-time PCR for identification of bacteria and detection of antibiotic resistance genes in adult and pediatric patients with hematological malignancies.

The PCR showed nine negative results that tested positive by $\mathrm{BC}$ and 12 that were positive by real-time PCR and negative by $\mathrm{BC}$. The negative real-time PCR results that were positive by $\mathrm{BC}$ failed to show frequent bloodstream pathogens such as CoNS, enterococci, streptococci and $K$. pneumoniae. Varani et al. have reported positive BC results for CoNS and Streptococcus mitis, which were not detected by real-time PCR [14]. Louie et al. have detected positive BC for Enter. Faecalis, whereas real-time PCR failed to identify this microorganism [15]. This difference allowed us to establish a limit of detection (LoD) to distinguish between infection and contamination. The low sensitivity of real-time PCR for CoNS, Enterococcus spp. and Str. pneumoniae was possibly associated with the $\mathrm{Ct}$ and LoD. Ct specifically sets analytical cutoff values to distinguish contamination from infection in bone marrow transplant patients. Lehmann et al. have reported the importance of determining cutoff values to discriminate between significant bacterial loads in clinical samples and low amounts of bacterial DNA [16]. In addition, the presence of a high bacterial DNA concentration might inhibit molecular detection [17].

In samples in which bacteria were only detected with real-time PCR, the microorganisms detected were one $A$. baumannii, two $K$. pneumoniae, one Enterococcus spp. and three CoNS (Table 1). Varani et al. have detected Gram-negative bacteria more than $\mathrm{BC}$ and Enterococcus spp. did not grow in culture [14]. Louie et al. have observed 17 cases in which PCR identified an organism that was not found by $\mathrm{BC}$ [15]. The previous use of antibiotics that is common in our patient population, including antibiotic prophylaxis, could contribute for these cases of bacteria only detected with real time PCR. Our cases that were positive for $K$. pneumoniae and A. baumannii showed genuine bacterial recovery because 19 days after PCR, K. pneumoniae was detected in another culture that was not available for real-time PCR. Others have suggested that the detection of circulating bacterial DNA and the presence of nonviable bacterial DNA detected by real-time PCR could be considered as contaminants $[16,18]$.

The real-time PCR detected Candida DNA in three samples from two patients with probable or possible BSI, whereas BC showed negative results. Differences among BC systems for detection of Candida spp. do not explain the disagreement with the real-time PCR $[19,20]$. Mancini et al. have detected Aspergillus spp. in blood samples by LightCycler SeptiFast (Roche Diagnostics, GmbH, Mannheim, Germany) [13]. The identification by real-time PCR was consistent with the presence of nonviable fungal components or of very low viable fungal loads [21,22].

The aim of our study was to detect 10 resistance genes. We found samples with blaSHV, blaCTX-M, van $\mathrm{A}$, and mecA genes by real-time PCR. Identification of these genes, together with clinical context, could be an important tool to help with the management of the appropriate therapy. One of the limitations of commercial kits for identifying bacteria and fungi in blood using 
PCR is failure to provide antimicrobial susceptibility patterns and resistance genes [14]. In our study, real-time PCR did not detect all the resistance genes; therefore, real-time PCR does not replace conventional bacteriology for antimicrobial agents.

The nonexistence of a gold standard regular diagnostic procedure is a major limitation for the evaluation of new molecular techniques. The positive $\mathrm{BC}$ results due to contamination represent a limitation for the interpretation of positive or negative real-time PCR results [23]. Karahan et al. have reported false-positive $\mathrm{BC}$ results that were suggestive of the presence of microbial DNA [24]. Accordingly, a negative result by real-time PCR cannot exclude the presence of BSI in neutropenic patients, and Peters et al. and Nakamura et al. have recommended that interpretation of real-time PCR results should conform to the clinical context $[23,25]$.

\section{Conclusion}

$\mathrm{BC}$ remains the gold standard for microbial diagnostics. However, real-time PCR could also be a valuable tool. Every effort should be made to improve the yield of this new diagnostic modality, particularly in critically ill patients. The results obtained should be interpreted together with clinical and other laboratory data. A large controlled study is in progress to evaluate further the clinical benefits of using real-time PCR in this patient setting.

\section{Competing interests}

The authors declare that they have no competing interests.

\section{Authors' contributions}

LCM participated in the design and coordination of the study, data analysis, and drafted the manuscript. TTR participated in the design of the study and carried out the PCR. KCB participated in the clinical data acquisition and carried out the Bactec experiments. CP participated in the design of the study. MGQ participated in the design of the study and carried out the PCR. FC participated in the design of the study. JSRO participated in the design of the study. ACCP participated in the design and coordination of the study and helped draft the manuscript. All authors read and approved the final manuscript.

\section{Acknowledgments}

This study was supported by a grant from "Fundação de Amparo à Pesquisa do Estado de São Paulo - FAPESP", Brazil. Conselho Nacional de Desenvolvimento Científico e Tecnológico -"National Counsel of Technological and Scientific Development" gave a grant to LCM (protocol 141636/2008-4), Brazil.

\section{Author details \\ ${ }^{1}$ Special Clinical Microbiology Laboratory (LEMC), Federal University of São Paulo/UNIFESP, São Paulo, Brazil. ${ }^{2}$ Division of Infectious Diseases, Federal University of São Paulo/UNIFESP, São Paulo, Brazil. ${ }^{3}$ GRAACC - Grupo de Apoio ao Adolescente e à Criança com Câncer (Support Group for Children and Adolescents with Cancer), São Paulo, Brazil. ${ }^{4}$ Division of Hematology, Federal University of São Paulo/UNIFESP, São Paulo, Brazil.}

Received: 2 March 2012 Accepted: 22 March 2013

Published: 5 April 2013

\section{References}

1. Biedenbach DJ, Moet GJ, Jones RN: Occurrence and antimicrobial resistance pattern comparisons among bloodstream infection isolates from the sentry antimicrobial surveillance program (1997-2002). Diagn Microbiol Infect Dis 2004, 50:59-69.

2. Marra AR, Camargo LF, Pignatari AC, Sukiennik T, Behar PR, Medeiros EA, Ribeiro J, Girão E, Correa L, Guerra C, Brites C, Pereira CA, Carneiro I, Reis M, de Souza MA, Tranchesi R, Barata CU, Edmond MB: Nosocomial bloodstream infections in Brazilian hospitals: analysis of 2,563 cases from a prospective nationwide surveillance study. J Clin Microbiol 2011, 49(5):1866-1871.

3. Kung HC, Hoyert DL, Xu J, Murphy SL: Deaths: final data for 2005. Nat/ Vital Stat Rep 2008, 56(10):1-120.

4. Tsalik EL, Jones D, Nicholson B, Waring L, Liesenfeld O, Park LP, Glickman SW, Caram LB, Langley RJ, Van Velkinburgh JC, Cairns CB, Rivers EP, Otero RM, Kingsmore SF, Lalani T, Fowler VG, Woods CW: Multiplex PCR to diagnose bloodstream infections in patients admitted from the emergency department with sepsis. J Clin Microbio/ 2010, 48(1):26-33.

5. Washington JA II, Ilstrup DM: Blood cultures: issues and controversies. Rev Infect Dis 1986, 8:792-802.

6. Mendes RE, Kiyota KA, Monteiro J, Castanheira M, Andrade SS, Gales AC, Pignatari ACC, Tufik S: Rapid detection and identification of metallo- $\beta$ lactamase encoding genes by multiplex real-time PCR assay and melt curve analysis. J Clin Microbiol 2007, 45:544-547.

7. Bispo PJ, Melo GB, Hofling-Lima AL, Pignatari ACC: Detection and gram discrimination of bacterial pathogens from aqueous and vitreous humor using real-time PCR assays. Invest Ophthalmol Vis Sci 2011, 52:873-881.

8. Carrigan SD, Scott G, Tabrizian M: Toward resolving the challenges of sepsis diagnosis. Clin Chem 2004, 50(8):1301-1314.

9. Garnacho-Montero J, Garcia-Garmendia JL, Barrero-Almodovar A, JimenezJimenez FJ, Perez-Paredes C, Ortiz-Leyba C: Impact of adequate empirical antibiotic therapy on the outcome of patients admitted to the intensive care unit with sepsis. Crit Care Med 2003, 31(12):2742-2751.

10. Leibovici L, Shraga I, Drucker M, Konigsberger H, Samra Z, Pitlik SD: The benefit of appropriate empirical antibiotic treatment in patients with bloodstream infection. J Intern Med 1998, 244(5):379-386.

11. Wu YD, Chen LH, Shang SQ, Lou JT, Du LZ, Zhao ZY: Gram stain specific probe based real-time PCR for diagnosis and discrimitation of bacterial neonatal sepsis. J Clin Microbio/ 2008, 46(8):2613-2619.

12. Ohlin A, Bäckman A, Björkqvist M, Mölling P, Jurstrand M, Schollin J: Realtime PCR of the 16S-rRNA gene in the diagnosis of neonatal bacteraemia. Acta Paediatr 2008, 97(10):1376-1380.

13. Mancini N, Clerici D, Diotti R, Perotti M, Ghidoli N, De Marco D: Molecular diagnosis of sepsis in neutropenic patients with haematological malignancies. J Med Microbiol 2008, 57(Pt 5):601-604.

14. Varani S, Stanzani M, Paolucci M, Melchionda F, Castellani G, Nardi L, Landini MP, Baccarani M, Pession A, Sambri V: Diagnosis of bloodstream infections in immunocompromised patients by real-time PCR. J Infect 2009, 58:346-351.

15. Louie RF, Tang Z, Albertson TE, Cohen S, Tran NK, Kost GJ: Multiplex polymerase chain reaction detection enhancement of bacteremia and fungemia. Crit Care Med 2008, 36(5):1487-1492.

16. Lehmann LE, Hunfeld KP, Emrich T, Haberhausen G, Wissing H, Hoeft A, Stuber F: A multiplex real-time PCR assay for rapid detection and differentiation of 25 bacterial and fungal pathogens from whole blood samples. Med Microbiol Immunol 2008, 197:313-324.

17. Lamoth F, Jaton K, Prod'hom G, Senn L, Bille J, Calandra T, Marchetti O Multiplex blood PCR in combination with blood cultures for improvement of microbiological documentation of infection in febrileneutropenia. J Clin Microbiol 2010, 48(10):3510-3516.

18. Ikegaya S, Iwasaki H, Ueda T: Clinical significance of coagulase-negative Staphylococci isolated from blood culture samples of patients with hematological disorders; true bacteremia or contamination. Rinsho Ketsueki 2010, 51:398-401.

19. Hebart H, Löffler J, Reitze H, et al: Prospective screening by a panfungal polymerase chain reaction assay in patients at risk for fungal infections: implications for the management of febrile neutropenia. $\mathrm{Br} J$ Haematol 2000, 111(2):635-640.

20. Badiee $P$, Kordbacheh $P$, Alborzi A: A Study on invasive fungal infections in immunocompromised patients to present a suitable early diagnostic procedure. Int J Infect Dis 2009, 13:97-102. 
21. Horvath LL, George BJ, Murray CK, Harrison LS, Hospenthal DR: Direct comparison of the BACTEC 9240 and BacT/ALERT 3D automated blood culture systems for candida growth detection. J Clin Microbiol 2004, 42:115-118.

22. Sandven P, Bevanger L, Digranes A, Haukland HH, Mannsaker T, Gaustad P: Candidemia in Norway (1991 to 2003): results from a nationwide study. J Clin Microbiol 2006, 44:1977-1981.

23. Peters RP, van Agtmael MA, Danner SA, Savelkoul PH, VandenbrouckeGrauls CM: New developments in the diagnosis of bloodstream infections. Lancet Infect Dis 2004, 4:751-760.

24. Karahan ZC, Mumcuoglu I, Guriz H, Tamer D, Balaban N, Aysev D, Akar N: PCR evaluation of false-positive signals from two automated bloodculture systems. J Med Microbiol 2006, 55:53-57.

25. Nakamura A, Sugimoto Y, Ohishi K, Sugawara Y, Fujieda A, Monma F, Suzuki K, Masuya M, Nakase K, Matsushima Y, Wada H, Katayama N, Nobori T: Diagnostic value of PCR analysis of bacteria and fungi from blood in empiric-therapy-resistant febrile neutropenia. J Clin Microbiol 2010, 48:2030-2036

doi:10.1186/1471-2334-13-166

Cite this article as: Menezes et al:: Diagnosis by real-time polymerase chain reaction of pathogens and antimicrobial resistance genes in bone marrow transplant patients with bloodstream infections. BMC Infectious Diseases 2013 13:166.

\section{Submit your next manuscript to BioMed Central and take full advantage of:}

- Convenient online submission

- Thorough peer review

- No space constraints or color figure charges

- Immediate publication on acceptance

- Inclusion in PubMed, CAS, Scopus and Google Scholar

- Research which is freely available for redistribution 